круглі столи; засідання вченої ради факультетів; методичні семінари; виробничі наради; засідання кафедр; інструктивно-методичні наради, які проводяться деканами факультетів; робочі групи; індивідуальна самоосвітня робота викладача; «Школа педагогічної майстерності»; «Майстер-клас»; виставка кращого навчально-методичного забезпечення дисциплін; конкурс на краще навчальне видання; огляд-конкурс за номінаціями «Краща кафедра», «Кращий викладач»; стажування; наставництво; взаємовідвідування занять.

Як бачимо, рівень педагогічної майстерності викладача вищої школи є важливим чинником навчально-виховного процесу, він позначається на результатах навчання студентів, на формуванні їх як особистостей. У свою чергу, розвиток педагогічної майстерності викладача корелює 3 його ставленням до себе, вимогами до своєї діяльності, особистісними якостями. Можна вивчити свій фаховий предмет, мати систему психологопедагогічних знань, але це не забезпечить відповідної майстерності.

Комплексне використання активних форм і методів сприяє закріпленню теоретичних знань, озброєнню викладачів необхідним методичним арсеналом розв'язання сучасних освітніх проблем вищої школи, формують здатність до рефлексії, уміння використовувати одержану інформацію в нових умовах, а також удосконалювати свої інтелектуальні, світоглядні і комунікативні якості.

Сучасна вища школа має багатий арсенал форм підвищення педагогічної майстерності науково-педагогічних працівників, для дипломованого фахівця різноманітні форми організації методичної роботи, організовані на робочому місці, є способом підвищення професійної майстерності. У подальшій своїй роботі ми плануємо вивчити досвід аграрних ВНЗ щодо використання педагогічних технологій та інтерактивних методів навчання.

\title{
Література
}

1. Заболоцька О. С. Компетентнісний підхід як освітня інновація: порівняльний аналіз / О. С. Заболоцька // Вісник Житомирського державного університету. - 2008. Випуск 40. - Педагогічні науки. - С. 63-68. 2. Зязюн I. А. Педагогічна майстерність / І. А. Зязюн. - Київ : Вища школа, 1997. - С. 30-49. 3. Ортинський В. Л. Педагогіка вищої школи: навч. посіб. [для студ. вищ. навч. закл.] / В. Л. Ортинський. - Київ : Центр учбової літератури, 2009. - 472 с. 4. Обривкіна О. М. Сучасні форми методичної роботи 3 підвищення педагогічної майстерності викладачів в університеті [Електронний ресурс]/ О. М. Обривкіна. Режим доступу: //www.nbuv. gov.ua/portal/soc_gum/nvnau_ppf/2010/10oom.pdf. 5. Фіцула М. М. Педагогіка вищої школи: [навч. посіб.] / М. М. Фіцула. - Київ : Академвидав, 2006. - 352 с.

УДК 378.147

Наталія Чувасова

\section{ФОРМУВАННЯ ТВОРЧОГО ПОТЕНЦІАЛУ МАЙБУТНІХ УЧИТЕЛІВ ХІМІЇ ТА БІОЛОГІЇ У ПРОЦЕСІ ФАХОВОЇ ПІДГОТОВКИ}

Чувасова Н. О. Формування творчого потенціалу майбутніх учителів хімії та біології у процесі фахової підготовки.

У статті на основі зіставлення, порівняння, узагальнення наукової інформації феноменів «творчість», «творча особистість», «потенціал», «творчий потенціал» розглядаються різні підходи до визначених понять. Виокремлено якості, чинники творчого потенціалу та риси його розвитку.

Ключові слова: творчість, творчий процес, творча особистість, творчий потенціал.

Педагогіка вищої та середної школи. - 2015. - Вип. 45 
Чувасова Н. А. Формирование творческого потенциала будущих учителей химии и биологии в процессе профессиональной подготовки.

В статье на основе сопоставления, сравнения, обобщения научной информации феноменов «творчество», «творческий процесс», «потенциал», «творческий потенциал» рассматриваются различные подходы к определению этих понятий. Выделены качества, факторы творческого потенциала и черты его развития.

Ключевые слова: творчество, творческий процесс, творческая личность, творческий потенциал.

Chuvasova N. A. Forming the creative potential of future teachers majoring in chemistry and biology in the process of training.

Different approaches to the definition of such concepts as «creativity», «creative process», «potential», «creative potential» are analyzed on the basis of comparison and compilation of scientific information.

Key words: creativity, creative process, creative personality, creative potential.

Формування творчої особистості майбутнього вчителя є сьогодні однією з актуальних проблем, оскільки підготовка до професійної діяльності досягає мети, якщо в результаті вдається сформувати ініціативного, творчо активного фахівця, здатного у свою чергу формувати творчу особистість учня. В умовах суспільної ситуації, що склалася на початку XXI століття в Україні, пріоритетом освіти стає становлення і розвиток творчої, активної особистості, з чітко вираженою суб'єктної позицією і творчим потенціалом. Важлива роль у цьому процесі належить учителям, професійна підготовка яких вимагає постійної модифікації, пошуку нових підходів, педагогічних технологій, прийомів і засобів.

Проблеми підготовки педагогічних кадрів, формування їхнього творчого потенціалу, розвитку творчих якостей, умінь, науково-педагогічного стилю мислення та діяльності висвітлюються у чисельних дослідженнях (Б. Ананьєв, В. Андреєв, І. Бех, Н. Вишнякова, В. Загвязинський, $\quad$ І. Зязюн, $\quad$ В. Кан-Калик, О. Клепіков, П. Кравчук, Н. Кузьміна, І. Кучерявий, О. Лук, А. Маслоу, О. Матюшкін, Я. Пономарьов, Н. Посталюк, М. Поташник, В. Радул, В. Рибалка, В. Роменець, С. Сисоєва, Т. Сущенко, О. Чаплигін та ін.).

А. Алексюк розглядає вищу педагогічну освіту як фундаментальну наукову, загальнокультурну і практичну підготовку фахівців, які визначатимуть темпи i рівень науково-технічного, економічного та соціально-культурного прогресу. На думку науковця, вища педагогічна освіта покликана сприяти формуванню інтелектуального потенціалу нації, усебічному розвитку особистості як найвищої цінності суспільства, стати могутнім чинником розвитку духовної культури українського народу, відтворення продуктивних сил України [1, с. 248].

Рушійною силою і джерелом розвитку особистості $є$ iї творчий потенціал. Ця проблема знайшла своє відображення у працях таких науковців, як: Б. Ананьєв, В. Асеєв, Є. Варламова, А. Матюшкін, М. Муканов, Я. Пономарьов, С. Рубінштейн, С. Степанов, Р. Ткач, Д. Узнадзе та інші. Вони розкривають саме поняття «творчий потенціал особистості», розглядаючи його на рівні вивчення потенційних і актуальних характеристик людини. Основна ідея у працях згаданих науковців полягає в тому, що творчий потенціал інтерпретується як категорійна форма творчої активності особистості. Динаміка й розвиток творчого потенціалу - це діалектичний процес переходу потенційного та інтелектуального в актуальне функціонування творчої активності, своєрідного плану продуктивної діяльності, іiі 
програми на основі ретроспекції та моделювання перспектив.

Поняття «творчий потенціал» вказує на зв'язок особи і творчості через індивідуальні якості особистості, її мотиваційну структуру, ціннісні орієнтації, активність. Так, П. Кравчук визначає творчий потенціал як сукупність можливостей цілеспрямованої перетворювальної діяльності, у якій відбивається характер взаємозв'язку усіх здібностей людини, як інтегративну якість, що визначає міру можливостей сутнісної творчої сили особистості в реальній практиці і наддіяльнісних взаємовідносинах і стосунках, підкреслюючи, що творчий потенціал $\epsilon$ властивістю особистості «взаємопов'язувати», інтегрувати іiі дії для цілеспрямованого подолання конкретної суперечності з метою виходу за межі звичайного, досягнутого. Цілісність особистості, на думку автора, є інтегральним явищем, що об'єднує різні якості особистості та виявляється за допомогою творчої сили, яка визначається змістом i рівнем розвитку потенційних можливостей до перетворення, «виявляє» себе завдяки творчим здібностям. Потенційні творчі можливості виявляються в діяльності за наявності певних причин і умов, причому результати творчості залежать також від ступеня розвитку творчого потенціалу [4, с. 24-25].

Н. Посталюк розглядає творчий потенціал як інтегрований вияв найрізноманітніших якостей особистості. Науковець уважає, що творчу особистість визначають не тільки високий творчий потенціал, але й ступінь іï активності в його реалізації [7, с. 49-50].

O. Клепіков, I. Кучерявий характеризують реалізацію творчого потенціалу особистості через ії активність. Поняття «творчий потенціал» науковці трактують як якість людини, за допомогою якої реалізується наявна і можлива діяльність у формі праці, пізнання і спілкування [5, с. 32].

I. Драч визначає творчий потенціал особистості як складне особистісно-діяльнісне утворення, яке сприяє появі нестандартних, оригінальних рішень і складається 3 таких компонентів: мотивація до активної пізнавальної діяльності (потяг до творчості, спрямованість на самореалізацію, пізнавальна потреба, спрямованість на досягнення мети, прагнення до успіху); творчі здібності (уява, пам'ять, нестандартне мислення, фантазія, інтуїція); досвід творчої діяльності (знання, уміння та навички щодо розв'язання нестандартних задач i прийняття нестандартних рішень); характерологічні особливості особистості (активність, ініціативність, упевненість, наполегливість, працездатність, комунікативність, організованість, самостійність) [8, с. 27].

Феномен творчого потенціалу $є$ цілісним, але внутрішньо суперечливим явищем, загальним і необхідним моментом суб'єктивної діяльної здатності людського індивіду. Це інтегральна властивість у вигляді здібності, що надає змогу людині здійснювати предметну діяльність. Означена властивість $є$ результатом природної й соціальної активності, що стимулюється певними умовами, і зовнішньо виявляється у праці або доцільній діяльності [1, c. 19].

С. Сисоєва вказує на реалізацію творчих можливостей особистості і в предметній діяльності, і в житті. Науковець обгрунтувала систему творчих якостей особистості, що відображає іï спрямованість на творчу діяльність, характерологічні особливості, творчі уміння, індивідуальні особливості психічних процесів, які сприяють успіху у творчій діяльності, і за рахунок яких людина здатна діяти як творчо-активний суб'єкт. Одноманітна педагогічна діяльність педагога, по-перше, знищує його самого як особистість і як педагога, по-друге, губить мотивацію діяльності та самовдосконалення у вихованців і, по-третє, формує таких же сірих особистостей [6, с. 119-120].

Творчий потенціал учителя не є суто природним даром, який отримує або не отримує

Педагогіка вищої та середної школи. - 2015. - Вип. 45 
людина з народження. Для вчителя здатність до творчого розв'язання педагогічних проблем $\epsilon$ неодмінною умовою його професійної діяльності. А отже розвиток творчих здібностей, творчого потенціалу майбутніх учителів завжди перебував i перебуває в центрі уваги системи педагогічної освіти.

Творча педагогічна діяльність майбутнього вчителя- це тільки одна грань педагогічної творчості, головним критерієм якої $\epsilon$ забезпечення творчого розвитку особистості учня. Творча педагогічна діяльність кожного майбутнього вчителя має свої індивідуальні особливості, а тому кожен студент потребує особливого до себе підходу.

Творчий потенціал, як динамічна структура особистості, охоплює комплекс творчих задатків, які виявляються і розвиваються у творчій діяльності, а також комплекс психічних новоутворень особистості протягом іiі вікового дозрівання. Він базується на уявленні i фантазії, асоціативних зв'язках, багатстві інтуїтивних процесів, емоційній різноманітності й емпатійних почуттях, які здійснюються у процесі творчої діяльності. На думку С. Степанова, творчий потенціал - це психоенергетична напруга, що виникає між устремліннями, можливостями та реальним життям людини. Він реалізується у рефлексивно-творчому зусиллі, тобто в зусиллі, спрямованому на досягнення раніше недосяжного, на реалізацію того, що до даного моменту не було реалізоване, на устремління за межі самого себе. За допомогою творчого зусилля людина може здобути у своєму житті те, що їй не було дано від природи або у процесі виховання та освіти. Воно і визначає унікальність і життєву стратегію особистості [7, с. 153].

B. Каменська та I. Мельникова розуміють творчий потенціал як особистісні особливості творчо обдарованої людини, пов'язані зі створенням ними нових матеріальних й ідеальних продуктів. Творчий потенціал - системне (багаторівневе, багатовимірне) психічне утворення, яке не тільки містить інтелектуальний потенціал, а й пов'язаний з мотивацією, емоціями, рівнем естетичного розвитку, екзистенційними, комунікативними параметрами, компетентністю тощо [1, с. 3].

Творчий потенціал особистості розглядається нині науковцями як складна, нелінійна, відкрита й самоорганізована система, яка визначає гуманістичну спрямованість світосприйняття, дій і вчинків, високу адаптивність, здатність до творчої самореалізації й духовного саморозвитку у просторі соціального і професійного життя. 3 огляду на такий зміст творчого потенціалу особистості в сучасних умовах саме ціннісно опосередкований творчий потенціал має стати головним об'єктом уваги у процесі розвитку особистості.

Для розуміння самої постановки питання про творчий потенціал особистості виокремлюють низку чинників: задатки (як вроджена якість), соціальне середовище (зовнішні умови впливу) і особистісна активність (життєва позиція особистості). Саме останній чинник визначає особистість як унікальну цілісну систему, яка є відкритою «можливістю» самоактуалізації, володіє потенціалом безперервного саморозвитку та самореалізації.

Якщо зусилля майбутнього вчителя хімії та біології перевищують за потужністю і реалізацією його наявні ресурси (прагнення й цінності особи вищі, ніж іiі актуальні ресурси), то він власними зусиллями збільшує свої ресурси й можливості (як психологічні, так і матеріальні), а отже й горизонти свого саморозвитку. У цьому випадку можна говорити, що студент, виявляючи творчий потенціал, одночасно його i нарощує. Творчий потенціал, реалізуючись у творчих зусиллях, пов'язує можливості студента і його реальне життя в єдиний процес життєтворчості, у якому кожна мить може бути народженням нових можливостей і їх реалізацією. 
Творчий потенціал майбутнього вчителя хімії та біології має комплексний характер i виявляється на всіх рівнях індивідуальності: на біопсихологічному, психологічному, соціальному й духовному. Як феномен, що розвивається, творчий потенціал має специфічні підструктури, взаємодія яких забезпечує сталість і цілісність творчих виявів людини, його динаміку в цілому.

Неоднозначність трактування поняття «творчий потенціал» означає, що воно є багатовимірним.

Творчий потенціал майбутнього вчителя хімії та біології, як і творча активність, мають тенденцію до самовираження і здобуття досягнень відповідно до їх можливостей. Мотивація ж творчої особистості виявляється в тенденції до пошуку й ризику, заснованих на бажанні досягнути й перевірити свої творчі можливості. Виходячи 3 головних постулатів гуманістичної психології, психології особистості школи С. Рубінштейна про безмежність можливостей розвитку творчого потенціалу, необхідно розуміти, що сама особистість тільки власним вибором може реалізувати або ж ні свою творчу унікальність (нарощувати чи зупиняти розвиток творчого потенціалу).

Творчий потенціал студента розуміється нами як невід'ємний складник сукупної культури майбутнього вчителя хімії та біології, що вміщує наявні та потенційні здатності й можливості до створення чогось нового або перетворення пізнаного, як відкритість особистості до змін та самовдосконалення. Одночасно творчий потенціал майбутнього вчителя є провідним чинником урізноманітнення та розвитку сукупної професійної культури педагога.

Водночас творчий потенціал студента не можна розглядати як статичний. Він динамічний, постійно зазнає трансформацій і є складником сукупної професійної культури майбутнього учителя хімії та біології, а отже, правомірно говорити про його розвиток у системі вищої педагогічної освіти.

Як бачимо, автори, говорячи про один феномен, удосконалюючи визначення творчого потенціалу, до змісту уводять все нові і нові нюанси, систематизацію яких спробувала подати О. Буторіна [3, с. 35]. Ось як розуміється творчий потенціал різними авторами:

- здатність до творчості;

- інтелектуальна творчість;

- щось нове, оригінальне;

- віддалені асоціації;

- реструктурування цілісної системи;

- незвичайне кодування інформації;

- дивергентне мислення;

- результат (або відсутність) внутрішньоособистісних конфліктів;

- вихід за межі вже наявних знань;

- нетрадиційне мислення, яке дозволяє швидко розв'язати проблемну ситуацію тощо.

Але i цей список неповний. Пишуть також про «ефективну самостійність» як системну якість, що є окремим виявом творчого потенціалу [8, с. 48].

Аналіз літератури з проблеми творчого потенціалу показав, що поняття «творчий потенціал» можна розглядати у двох напрямках: творчий потенціал як психічний процес $\mathrm{i}$ творчий потенціал як творче ставлення до життя.

По суті творчий потенціал у широкому сенсі - це структура характеристик, властивих творчим особистостям. При цьому якщо творчий потенціал у вузькому сенсі вимірюємо, то в 
широкому сенсі - тільки прогнозуємо з урахуванням ступеня вираженості особистісних особливостей. Тому вивести якийсь узагальнений показник (коефіцієнт) творчого потенціалу досить важко [1, с. 56].

На основі аналізу психолого-педагогічних досліджень можна виокремити такі найважливіші риси розвитку творчого потенціалу майбутніх учителів хімії та біології:

- високий рівень соціальної і моральної свідомості;

- пошуково-перетворювальний стиль мислення;

- розвинені інтелектуально-логічні здібності (уміння аналізувати, обгрунтовувати, пояснювати, виокремлювати головне тощо);

- проблемне бачення ситуацій та подій;

- творча фантазія, розвинена уява;

- специфічні особистісні якості (любов до дітей, безкорисливість, сміливість, готовність до розумного ризику у професійній діяльності, цілеспрямованість, допитливість, самостійність, наполегливість, ентузіазм);

- специфічні мотиви (необхідність реалізувати своє «Я», бажання бути визнаним, творчий інтерес, захопленість творчим процесом, своєю працею, прагнення досягти найбільшої результативності в конкретних умовах своєї педагогічної праці);

- комунікативні здібності;

- здатність до самоуправління;

- високий рівень загальної культури.

Отже, творчий потенціал як ціннісно-особиста категорія $\epsilon$ суттєвим резервом самоактуалізації майбутніх учителів хімії та біології і значною мірою постає своєрідним механізмом адаптації особистості до соціальних змін. Для того щоб внутрішньо відповідати сучасній дійсності, студент має не просто адаптуватися до нової ситуації, а й бути спроможним змінювати іiі, змінюючись і розвиваючись при цьому сам.

Важливість проблеми формування творчого потенціалу майбутніх учителів хімії та біології у процесі навчання у вищих навчальних закладах визначають ії значення: соціальне, тому що формується не просто нова людина з особливим складом мислення, здатна до радикальних змін і перетворень, а спеціаліст нової формації, який долучиться до прогресивних перетворень у суспільстві; наукове, тому що слугує засобом пізнання творчих здібностей у галузі педагогічної творчості.

Творчий потенціал особистості не є сталим явищем, багажем, який людина носить все життя в незмінному вигляді. Він змінюється, розвивається, збагачується, і в цьому розумінні $\epsilon$ невичерпним. Не може бути й певної норми розвитку творчого потенціалу або якогонебудь загального стандарту. Рівень розвитку творчого потенціалу в кожного студента свій. Цей факт виключає усереднення в освіті, зумовлює необхідність особистісно зорієнтованого навчання, урахування специфіки професійної підготовки студентів, їх інтересів і потреб, здібностей і можливостей.

3 огляду на викладене, ми розуміємо творчий потенціал майбутнього вчителя хімії та біології як відносно самостійну, динамічну систему, інтегральну властивість особистості, що відображає їі мотиваційно-творчу активність і спрямованість особистості, характерологічні особливості, досвід творчої діяльності, індивідуальні особливості психічних процесів, які виявляються як здатність інтегрувати іiі дії для цілеспрямованого перетворення життєвих i професійних педагогічних ситуацій і забезпечують розвивальну взаємодію особистості 3 соціальною дійсністю. 


\section{Література}

1. Алексюк А. М. Педагогіка вищої освіти України. Історія. Теорія: [підручник] / А. М. Алексюк. - Київ : Либідь, 1998. - 560 с. 2. Барышева Т. А. Психолого-педагогические основы развития креативности: [учеб. пособие] / Т. А. Барышева, Ю. А. Жигалов. - СанктПетербург : СПГУТД. - 2006. - 268 с. 3. Буторина О. В. Кросскультурное исследование креативности в управленческом потенциале руководителя / О. В. Буторина // Психология XXI века - Санкт-Петербург : СПГУТД, 2003. - С. 276-278. 4. Кравчук П. Ф.Творческий потенциал как интегративное качество личности / П. Ф. Кравчук // Становление человека в творчестве: [темат. сб.]. - Москва, 1994. - 360 с. 5. Основи творчості особи : [ посібник для студ. вищ. навч. закладів] / О. І. Клепіков, І. Т. Кучерявий. - Київ : Вища школа, 1996. 295 с. 6. Основи педагогічної творчості: [підручник] / С. О. Сисоєва. - Київ : Міленіум, 2006.- 344 с. 7. Посталюк Н. Ю. Творческий стиль деятельности: педагогический аспект / Наталья Юрьевна Посталюк. - Казань : Издательство Казанского университета, 1989. - 204 с. 8. Романцов М. Г. Креативный фактор и привлекательность избранной студентами специальности / М. Г. Романцева // Ананьевские чтения : [тезисы научно-практической конференции]. - Санкт-Петербург, 2001. - С. 185-186. 